\title{
Effect of growth regulator treatment on bud sprouting of hardwood cutting in different ornametal plants
}

\author{
Ramandeep Kaur* and H. S. Grewal \\ Department of Floriculture and Landscaping, Punjab Agricultural University, Ludhiana - 141004 (Punjab), INDIA \\ *Corresponding Author. E-mail: rkaur912@yahoo.com \\ Received: December 21, 2016; Revised received: April 8, 2017; Accepted: September 25, 2017
}

\begin{abstract}
The hardwood cuttings of Calliandra haematocephala, Cassia biflora, Pyrostegia venusta and Clerodendrum splendens were treated with different growth regulator concentrations and combinations (T1: NAA100 mg/l, T2: NAA 300 mg/l, T3: NAA 500 mg/l, T4: IBA100 mg/l, T5: IBA 300 mg/l, T6: IBA 500 mg/l, T7: NAA 100 mg/l + IBA 50 mg/l, T8: NAA 50 mg/l + IBA100 mg/l, T9: NAA 100 mg/l + IBA100 mg/l and T10: Control) for $12 \mathrm{~h}$ and planted either in polybags containing soil or in sand beds for callusing. The treatment of hardwood cuttings with T6: IBA (500 mg/l) for $12 \mathrm{~h}$ resulted in the maximum (33.33\%) mean per cent sprouting 60 days after direct planting in all the four genotypes. Among the genotypes, the per cent sprouting was significantly more in $C$ haematocephala(47.33\%), followed by $P$ venusta (8.66\%), $C$ splendens $(7.33 \%)$ and $C$ biflora $(7.33 \%)$, irrespective of the growth regulator treatment. The hardwood cuttings, planted in the sand beds for callusing (2 weeks) exhibited the maximum $(28.33 \%)$ mean per cent sproutingwith T6: IBA (500 mg/l, 12h), 60 days after transplanting in the polybags in all the four genotypes. Among the genotypes, the per cent sprouting was significantly more in $C$ haematocephala(48.67\%), followed by $P$ venusta $(6.67 \%)$ and $C$ splendens $(2.67 \%)$, irrespective of the growth regulator treatment, however, the cuttings failed to exhibit sproutingin $C$ biflora. The treatment of cutting with IBA $500 \mathrm{mg} / \mathrm{l}$ increase the sprouting percentage in $C$ haematocephala, $P$ venusta and $C$ splendens which otherwise were difficult to propagate through cutting.
\end{abstract}

Keywords: Calliandra haematocephala, Growth Regulators, Hardwood cutting, IBA, NAA

\section{INTRODUCTION}

The ornamental shrubs and climbers rank next to the trees in landscape plant material especially where space is less for planting of the trees. Calliandra haematocephala (Leguminosae) and Cassia biflora (Leguminosae) are woody perennials shrubs with multiple stem and valued for their attractive shape, flowers and flower colour. Likewise, Pyrostegia venusta (Bignoniaceae) and Clerodendrum splendens (Verbenaceae) are also woody perennials climbers with multiple stem and bear modified organs (tendrils, thorns, rootlets etc.) to climb up the support (Arora, 2013).Vegetative propagation is the most important method for large scale propagation and is widely used for quick establishment of new plantations. The propagation of plants through layering in $C$ haematocephala, $C$ biflora and $P$ venusta and root cuttings in $C$ splendens limits the propagation due to extensive damage of the mother plants while propagation, However, the propagation of plants through cuttings is advantageous and treatment with synthetic growth regulators (Naphthalene acetic acid NAA and Indole butyric acid IBA) have been reported to improve rooting in many ornamental plants. The treatment of cuttings with combination of both IBA and NAA had significant effect on rooting of cuttings in Tecomella undulata (Karami and Salehi,
2010). In Coriaria nepalensis that cuttings resulted in the best rooting with IBA $100 \mathrm{mg} / \mathrm{l}$ treatment (Joshi et al 1992). The application of IBA significantly increased rooting of cutting in Prunus spp. (Ribeiro et al., 2010). The plant growth regulator treatments for short- and long - duration to induce rooting of cuttings have, therefore, been used by many research workers. The present investigation was undertaken in hard to root cuttings of four genotypes ( $C$ haematocephala, $C$ biflora, $P$ venusta and $C$ splendens) by treating with different growth regulator concentrations and combinations for 12 hand planting directly in (i) polybags containing soil directly or (ii) after callusing in sand beds.

\section{MATERIALS AND METHODS}

This experiment was conducted at Department of floriculture and landscaping, Punjab Agricultural University, Ludhiana during 2012-13. The hardwood cuttings $(\approx 15 \mathrm{~cm}$ long and thickness $\approx 5 \mathrm{~mm})$ of $C$ haematocephala, C biflora, $P$ venusta and $C$ splenden $s$ with uniform number of nodes (3-4) were prepared by giving slanting cut above the shoot bud on upper end and a straight cut below the basal bud (Hartmann et al.,2009). The cuttings were treated with different concentration of NAA, IBA or their combinations, for $12 \mathrm{~h}$ viz. T1: NAA100 mg/l, T2: NAA 300 mg/l, T3: NAA 500 mg/ 
1, T4: IBA100 mg/l, T5: IBA 300 mg/l, T6: IBA 500 $\mathrm{mg} / \mathrm{l}, \mathrm{T} 7$ : NAA $100 \mathrm{mg} / \mathrm{l}+\mathrm{IBA} 50 \mathrm{mg} / \mathrm{l}$, T8: NAA 50 $\mathrm{mg} / \mathrm{l}+\mathrm{IBA} 100 \mathrm{mg} / \mathrm{l}$, T9: NAA $100 \mathrm{mg} / \mathrm{l}+$ IBA100 $\mathrm{mg} / \mathrm{l}$ and T10: Control). The cuttings were treated with different concentration or their combinations of growth regulator by dipping basal end $\left(\approx 1.0^{\prime \prime}\right)$ of cuttings in the jars containing $100 \mathrm{ml}$ of solution. The treated cuttings were planted directly either (i) in garden soil in the polybags or (ii) in the sand bed for callusing. The cuttings were transplanted after 2 weeks in poly bags (5" x7") containing the garden soil after callusing. The observations with respect to sprouting of shoot buds were recorded at 30-, 45- and 60 days after planting. The data was statistically analyzed using factorial completely randomized block design (Fisher, 1950).

\section{RESULTS AND DISCUSSION}

Per cent sprouting 30 days: In all the four ornamental plants viz.Calliandra haematocephala, Cassia biflora, Pyrostegia venusta, and Clerodendrum splendens, planted after growth regulator treatments $(12 \mathrm{~h})$, it was observed that the treatment of cuttings with growth regulators had significant effect on per cent sprouting 30 days after direct planting (Table $1)$. The mean per cent sprouting was at par in treatment with T5: IBA $300 \mathrm{mg} / 1$ (15.00\%) and T6: IBA $500 \mathrm{mg} / \mathrm{l}(20.00 \%)$ and significantly better than all the other treatments, however, the minimum sprouting $(1.66 \%)$ was observed in the control. Among the genotypes, the per cent sprouting was significantly more in $C$ haematocephala $(34.00 \%)$, followed by $C$. splendens $(5.33 \%)$, P venusta $(4.67 \%)$ and $C$. biflora $(2.67 \%)$, irrespective of growth regulator treatment. Likewise, the hardwood cuttings treated with growth regulators planted after callusing had significant effect on per cent sprouting 30 days after planting (Table 1). The mean per cent sprouting $(8.33 \%)$ was at par in treatment with T6: IBA $500 \mathrm{mg} / \mathrm{l}$ and T2: NAA 300 $\mathrm{mg} / \mathrm{l}(8.33 \%)$, T9: NAA $100 \mathrm{mg} / \mathrm{l}+$ IBA100 mg/l $(8.33 \%)$ and significantly better than all the other treatments, however, the minimum sprouting $(1.67 \%)$ was observed in the control. Among the genotypes, the per cent sprouting was significantly more in $C$. haematocephala $(20.00 \%)$ and no sprouting was observed in $C$ biflora, $P$. venusta and $C$. splendens. Bud break percentage was enhanced by the application of IBA in conformity with the earlier findings in the Desmodium elegans (Chauhan et al., 1996), Ficus glomerata L. (Bhatt and Badoni,1993), agroforestery trees (Bhatt and Todaria,1990) and Glycyrrhiza glabra linn. (Masoodi et al., 1994). Similarly, in Bougainvillea peruviana cv. Shubra, the treatment of cuttings with IBA $500 \mathrm{ppm}$ resulted in significantly more sprouting (71.67\%) and establishment of plant (51.67\%) than all other treatments, irrespective of duration $(12,24 \mathrm{~h})$ of treatment and method of planting (Singh, 2000). The cuttings of $C$ biflora, $P$ venusta and $C$ splendens failed to sprout might be due to higher concentrations beyond tolerable limits of cuttings leading to toxicity of the exogenously applied substances (Hartmann et al., 2009). Sofi et al., (2016) reported that treatment of Acer caesium cutting with with IBA@8000 ppm showed maximum sprouting (74.50\%). Stem cuttings of Clerodendrum splendens proved superior when treated with $20 \%$ IBA followed by $10 \%$ IBA. It was also suggested that stem cuttings need IBA at the rate of $20 \%$, while root cuttings should be used without treating with IBA (Jamal et al.,2016).

Per cent sprouting after 45 days: It was observed that the treatment of cuttings with growth regulators had significant effect on per cent sprouting 45 days after direct planting in all the genotypes (Table 2), however, the mean per cent sprouting was significantly more in T6: IBA $500 \mathrm{mg} / \mathrm{l}(25.00 \%)$ than all the other treatments. The differences were non significant among rest of the treatments except T9: NAA $100 \mathrm{mg} / \mathrm{l}$ + IBA $100 \mathrm{mg} / 1(11.66 \%)$ and the control $(3.33 \%)$. Among the genotypes, the per cent sprouting was significantly more in $C$ haematocephala $(40.00 \%)$, followed by $C$ splendens $(6.66 \%), P$ venusta, $(6.66 \%)$ and $C$ biflora $(5.33 \%)$, irrespective of the growth regulator treatment. It was observed that treatment of cuttings with growth regulators for callusing had significant effect on per cent sprouting 45 days after planting (Table 2). The mean per cent sprouting was the maximum $(23.33 \%)$ in treatment with T6: IBA $500 \mathrm{mg} / 1$ and at par among the T7: NAA $100 \mathrm{mg} / \mathrm{l}+\mathrm{IBA} 50 \mathrm{mg} /$ $1(16.67 \%)$, T5: IBA $300 \mathrm{mg} / 1(15.00 \%)$ and T3: NAA $500 \mathrm{mg} / \mathrm{l}(15.00 \%)$. The minimum sprouting $(1.67 \%)$ of cuttings was observed in the control. Among the genotypes, the per cent sprouting was significantly more in $C$. haematocephala $(36.67 \%)$ followed by $C$. splendens $(5.33 \%)$, P. venusta $(2.00 \%)$, whereas, the cuttings failed to exhibit sprouting in C. biflora.

Hartmann et al. (2009) reported that IBA was the best auxin for general use because it was nontoxic to plants over a wide range of concentration than NAA, and was effective in promoting rooting of a large number of plant species. Cong (1991) also reported that Prunus triloba cuttings treated with IBA $500 \mathrm{ppm}$ and planted in earthen pots containing garden soil resulted in the maximum survival of plants. Akhtar et al. (2015) observed that Rosa centifolia stem cuttings of treated with IBA $450 \mathrm{ppm}$ produced maximum shoot length $(10.67 \mathrm{~cm})$. Ficus benjamina hard wood cuttings treated with IBA at $1000 \mathrm{ppm}$ take minimum days to sprouting ( Ingole et al., 2016). Ratnamala et al., (2014) reported that the hardwood cuttings of Phalsa treated with IBA at $200 \mathrm{ppm}$ resulted in minimum number of days taken for sprouting (9.34), maximum number of sprouts per cutting (5.30).

Per cent sprouting after 60 days: It was observed that the treatment of cuttings with growth regulators had significant effect on per cent sprouting even 60 
Ramandeep Kaur and H. S. Grewal / J. Appl. \& Nat. Sci. 9 (4): 2068 - 2072 (2017)

Table 1. Effect of growth regulator treatments (12h) on per cent sprouting in Calliandra haematocephala, Cassia biflora, Pyrostegia venusta and Clerodendrum splendens after 30 days of planting.

\begin{tabular}{|c|c|c|c|c|c|c|c|c|c|c|c|}
\hline \multirow[t]{2}{*}{$\begin{array}{l}\text { Treat- } \\
\text { ments }\end{array}$} & \multirow{2}{*}{$\begin{array}{l}\text { Growth } \\
\text { regulator } \\
\text { concen- } \\
\text { tration } \\
(\mathrm{mg} / \mathrm{l}) \\
\end{array}$} & \multicolumn{5}{|c|}{$\begin{array}{l}\text { Per cent sprouting of cuttings after } \\
\text { direct planting }\end{array}$} & \multicolumn{5}{|c|}{$\begin{array}{c}\text { Per cent sprouting of cuttings after } \\
\text { callusing }\end{array}$} \\
\hline & & $\begin{array}{c}\text { C haem- } \\
\text { atocephal } \\
a \\
\end{array}$ & $\begin{array}{l}\text { C biflo- } \\
\text { ra }\end{array}$ & $\begin{array}{c}P \\
\text { venusta }\end{array}$ & $\begin{array}{l}\text { C splen- } \\
\text { dens }\end{array}$ & Mean & $\begin{array}{c}\text { Chaemato- } \\
\text { cephala }\end{array}$ & $\begin{array}{c}\text { C biflo- } \\
\text { ra }\end{array}$ & $\begin{array}{c}P \\
\text { venusta }\end{array}$ & $\begin{array}{l}\text { C splen- } \\
\text { dens }\end{array}$ & Mean \\
\hline $\mathrm{T}_{1}$ & NAA100 & 33.33 & 0.00 & 0.00 & 6.66 & 10.00 & & 0.00 & 0.00 & 0.00 & .66 \\
\hline $\mathrm{T}_{2}$ & NAA300 & 33.33 & 0.00 & 6.66 & 0.00 & 10.00 & 33.33 & 0.00 & 0.00 & 0.00 & 8.33 \\
\hline $\mathrm{T}_{3}$ & NAA500 & 40.00 & 6.66 & 0.00 & 6.66 & 13.33 & 13.33 & 0.00 & 0.00 & 0.00 & 3.33 \\
\hline $\mathrm{T}_{4}$ & IBA100 & 20.00 & 0.00 & 13.33 & 13.33 & 11.66 & & 0.00 & 0.00 & 0.00 & 3.33 \\
\hline $\mathrm{T}_{5}$ & IBA300 & 40.00 & 6.66 & 13.33 & 0.00 & 15.00 & 26.67 & 0.00 & 0.00 & 0.00 & 6.66 \\
\hline $\mathrm{T}_{6}$ & IBA500 & 53.33 & 6.66 & 13.33 & 6.66 & 20.00 & 33.33 & 0.00 & 0.00 & 0.00 & 8.33 \\
\hline $\mathrm{T}_{7}$ & $\begin{array}{l}\text { NAA100+I } \\
\text { BA50 }\end{array}$ & 26.66 & 6.66 & 0.00 & 13.00 & & 20.00 & 0.00 & 0.00 & 0.00 & 5.00 \\
\hline $\mathrm{T}_{8}$ & $\begin{array}{l}\text { NAA50+ } \\
\text { IBA100 }\end{array}$ & 40.00 & 0.00 & 0.00 & 6.66 & 1.66 & 13.33 & 0.00 & 0.00 & 0.00 & 3.33 \\
\hline $\mathrm{T}_{9}$ & $\begin{array}{l}\text { NAA100+ } \\
\text { IBA100 }\end{array}$ & 46.66 & 0.00 & 0.00 & 0.00 & 11.66 & 33.33 & 0.00 & 0.00 & 0.00 & 8.33 \\
\hline $\mathrm{T}_{10}$ & $\begin{array}{l}\text { Control } \\
\text { Mean }\end{array}$ & $\begin{array}{l}6.66 \\
34.00\end{array}$ & $\begin{array}{l}0.00 \\
2.67\end{array}$ & $\begin{array}{l}0.00 \\
4.67\end{array}$ & $\begin{array}{l}0.00 \\
5.33\end{array}$ & 1.66 & $\begin{array}{l}6.67 \\
20.00\end{array}$ & $\begin{array}{l}0.00 \\
0.00\end{array}$ & $\begin{array}{l}0.00 \\
0.00\end{array}$ & $\begin{array}{l}0.00 \\
0.00\end{array}$ & 1.67 \\
\hline
\end{tabular}

L.S.D. $(p=0.05)$ : Growth regulator concentration $(A)=5.05$; Gen-L.S.D. $(p=0.05)$ : Growth regulator concentraotypes $(B)=7.99$; Interaction $(A \times B)=15.98 \quad$ tion $(A)=2.81$; Genotypes $(B)=4.45$; Interaction $(\mathrm{A} \times \mathrm{B})=8.89$

Table 2. Effect of growth regulator treatments (12h) on per cent sprouting in Calliandra haematocephala, Cassia biflora, Pyrostegia venusta and Clerodendrum splendens after 45 days of planting.

\begin{tabular}{|c|c|c|c|c|c|c|c|c|c|c|}
\hline \multirow{3}{*}{$\begin{array}{l}\text { Treat Growth } \\
\text { ments regulator } \\
\text { concentration } \\
(\mathrm{mg} / \mathrm{l})\end{array}$} & \multicolumn{5}{|c|}{$\begin{array}{c}\text { Per cent sprouting of cuttings after direct } \\
\text { planting }\end{array}$} & \multicolumn{5}{|c|}{$\begin{array}{c}\text { Per cent sprouting of cuttings after cal- } \\
\text { lusing }\end{array}$} \\
\hline & $\begin{array}{l}\text { C haemato- } \\
\text { cephala }\end{array}$ & $\begin{array}{l}\text { C biflo- } \\
\text { ra }\end{array}$ & $\begin{array}{c}P \\
\text { venust }\end{array}$ & $\begin{array}{l}\text { C splen- } \\
\text { dens }\end{array}$ & Mean & $\begin{array}{l}\text { C haemato- } \\
\text { cephala }\end{array}$ & $\begin{array}{c}C \\
\text { biflo- }\end{array}$ & $\begin{array}{c}P \\
\text { venust }\end{array}$ & $\begin{array}{l}\text { C splen- } \\
\text { dens }\end{array}$ & $\begin{array}{c}\text {-Mea } \\
\mathbf{n}\end{array}$ \\
\hline & 40.00 & 6.66 & $\begin{array}{r}\boldsymbol{a} \\
0.00\end{array}$ & 6.66 & 13.33 & 33.33 & $\begin{array}{r}\boldsymbol{r} \boldsymbol{a} \\
0.00\end{array}$ & $\begin{array}{r}\boldsymbol{a} \\
0.00\end{array}$ & 0.00 & 8.33 \\
\hline $\mathrm{T}_{2} \mathrm{NAA} 300$ & 40.00 & 0.00 & 6.66 & 6.66 & 13.33 & 13.33 & 0.00 & 0.00 & 0.00 & 3.33 \\
\hline $\mathrm{T}_{3} \quad \mathrm{NAA} 500$ & 46.66 & 13.33 & 0.00 & 0.00 & 15.00 & 60.00 & 0.00 & 0.00 & 0.00 & $\begin{array}{l}15.0 \\
0\end{array}$ \\
\hline $\mathrm{T}_{4} \quad$ IBA100 & 46.66 & 6.66 & 13.33 & 0.00 & 16.66 & 20.00 & 0.00 & 6.67 & 13.33 & $\begin{array}{l}10.0 \\
0\end{array}$ \\
\hline $\mathrm{T}_{5} \quad$ IBA300 & 26.66 & 6.66 & 26.66 & 13.33 & 18.33 & 53.33 & 0.00 & 6.67 & 0.00 & $\begin{array}{l}15.0 \\
0\end{array}$ \\
\hline $\mathrm{T}_{6} \quad$ IBA500 & 66.66 & 6.66 & 20.00 & 6.66 & 25.00 & 66.67 & 0.00 & 6.67 & 20.00 & $\begin{array}{l}23.3 \\
3\end{array}$ \\
\hline $\begin{array}{ll}\mathrm{T}_{7} & \mathrm{NAA} \\
100+\mathrm{IBA} 50\end{array}$ & 26.66 & 13.33 & 0.00 & 26.66 & 16.66 & 26.66 & 0.00 & 0.00 & 6.67 & $\begin{array}{l}16.6 \\
7\end{array}$ \\
\hline $\begin{array}{ll}\mathrm{T}_{8} & \mathrm{NAA} 50+\mathrm{IBA} 10 \\
& 0\end{array}$ & 46.66 & 0.00 & 0.00 & 6.66 & 13.33 & 33.33 & 0.00 & 0.00 & 0.00 & 3.33 \\
\hline $\begin{array}{l}\mathrm{T}_{9} \\
\text { NAA10100+ } \\
\text { IBA100 }\end{array}$ & 46.66 & 0.00 & 0.00 & 0.00 & 11.66 & 53.33 & 0.00 & 0.00 & 13.33 & 8.33 \\
\hline $\mathrm{T}_{10}$ Control & 13.33 & 0.00 & 0.00 & 0.00 & 3.33 & 6.67 & 0.00 & 0.00 & 0.00 & 1.67 \\
\hline $\begin{array}{l}\quad \text { Mean } \\
\text { L.S.D. }(\mathrm{p}=0.05): \text { Grc } \\
\text { types }(\mathrm{B})=10.49 ; \text { Int }\end{array}$ & $\begin{array}{l}40.00 \\
\text { pwth regulat } \\
\text { eraction }(A \times\end{array}$ & $\begin{array}{l}5.33 \\
\text { concentr }\end{array}$ & $\begin{array}{c}6.66 \\
\text { ration }\end{array}$ & $\begin{array}{l}6.66 \\
\text { A) }=6 .\end{array}$ & ; Ger & $\begin{array}{l}36.67 \\
\text {-L.S.D. }(\mathrm{p}= \\
\text { tration (A) } \\
\text { Interaction }(\end{array}$ & $\begin{array}{l}0.00 \\
\text { 5): Gro } \\
.19 ; \mathrm{G} \\
3)=13\end{array}$ & $\begin{array}{l}2.00 \\
\text { owth reg } \\
\text { Jenotype } \\
3.27\end{array}$ & $\begin{array}{l}5.33 \\
\text { gulator }\end{array}$ & $\begin{array}{r}8.33 \\
\text { oncen- } \\
=6.63\end{array}$ \\
\hline
\end{tabular}


Table 3. Effect of growth regulator treatments (12h) on per cent sprouting in Calliandra haematocephala, Cassia biflora, Pyrostegia venusta and Clerodendrum splendens after 60 days of planting.

\begin{tabular}{|c|c|c|c|c|c|c|c|c|c|c|c|}
\hline \multirow{2}{*}{$\begin{array}{l}\text { Treat- } \\
\text { ments }\end{array}$} & \multirow{2}{*}{$\begin{array}{l}\text { Growth } \\
\text { regulator } \\
\text { concentra- } \\
\text { tion }(\mathrm{mg} / \mathrm{l}) \\
\end{array}$} & \multicolumn{5}{|c|}{ Per cent sprouting of cuttings after direct planting } & \multicolumn{5}{|c|}{ Per cent sprouting of cuttings after callusing } \\
\hline & & $\begin{array}{l}\text { Chaema- } \\
\text { tocephala }\end{array}$ & C biflora & Pvenusta & $\begin{array}{c}C \\
\text { splandens }\end{array}$ & Mean & $\begin{array}{l}\text { C haema- } \\
\text { tocephala }\end{array}$ & C biflora & P venusta & $\begin{array}{c}\text { C splen- } \\
\text { dens }\end{array}$ & Mean \\
\hline $\mathrm{T}_{1}$ & NAA100 & 46.66 & 13.33 & 0.00 & 6.66 & 16.66 & 46.67 & 0.00 & 0.00 & 0.00 & 11.67 \\
\hline $\mathrm{T}_{2}$ & NAA300 & 53.33 & 13.33 & 0.00 & 0.00 & 16.66 & 40.00 & 0.00 & 0.00 & 0.00 & 10.00 \\
\hline $\mathrm{T}_{3}$ & NAA500 & 46.66 & 6.66 & 13.33 & 6.66 & 18.33 & 46.67 & 0.00 & 26.67 & 0.00 & 18.33 \\
\hline $\mathrm{T}_{4}$ & IBA100 & 46.66 & 6.66 & 6.66 & 0.00 & 15.00 & 26.66 & 0.00 & 0.00 & 0.00 & 6.67 \\
\hline $\mathrm{T}_{5}$ & IBA300 & 46.66 & 0.00 & 33.33 & 13.33 & 23.33 & 60.00 & 0.00 & 20.00 & 6.67 & 21.67 \\
\hline $\mathrm{T}_{6}$ & IBA500 & 80.00 & 13.33 & 26.66 & 13.33 & 33.33 & 93.33 & 0.00 & 6.67 & 13.33 & 28.33 \\
\hline $\mathrm{T}_{7}$ & $\begin{array}{c}\text { NAA100+I } \\
\text { BA } 50\end{array}$ & 46.66 & 6.66 & 0.00 & 0.00 & 13.33 & 46.67 & 0.00 & 6.67 & 0.00 & 13.33 \\
\hline $\mathrm{T}_{8}$ & $\begin{array}{l}\text { NAA50+ } \\
\text { IBA100 }\end{array}$ & 33.33 & 6.66 & 0.00 & 26.66 & 16.66 & 40.00 & 0.00 & 0.00 & 0.00 & 10.00 \\
\hline $\mathrm{T}_{9}$ & $\begin{array}{l}\text { NAA100+ } \\
\text { IBA100 }\end{array}$ & 53.33 & 0.00 & 6.66 & 6.66 & 16.66 & 73.33 & 0.00 & 6.67 & 6.67 & 21.67 \\
\hline \multirow[t]{2}{*}{$\mathrm{T}_{10}$} & Control & 20.00 & 6.66 & 0.00 & 0.00 & 6.67 & 13.33 & 0.00 & 0.00 & 0.00 & 3.33 \\
\hline & Mean & 47.33 & 7.33 & 8.66 & 7.33 & & 48.67 & 0.00 & 6.67 & 2.67 & \\
\hline
\end{tabular}

L.S.D. $(p=0.05)$ : Growth regulator concentration $(A)=7.27$; Genotypes L.S.D. $(p=0.05)$ : Growth regulator concentration $(A)$ $(B)=11.49$; Interaction $(A \times B)=N S$

$=5.31$; Genotypes $(\mathrm{B})=8.39$; Interaction $(\mathrm{A} \times \mathrm{B})=$ 16.78

days after direct planting in all the genotypes (Table $3)$. The mean per cent sprouting was significantly more in T6: IBA $500 \mathrm{mg} / \mathrm{l}(33.33 \%)$ than all the other treatments, however, the differences were non significant among T5: IBA $300 \mathrm{mg} / \mathrm{l}(23.33 \%)$, T3: NAA $500 \mathrm{mg} /$ $1(18.33 \%)$, T1: NAA $100 \mathrm{mg} / \mathrm{l}$, T2: NAA $300 \mathrm{mg} / \mathrm{l}$, T8: NAA $50 \mathrm{mg} / \mathrm{l}+$ IBA $100 \mathrm{mg} / \mathrm{l}$ and T9: NAA 100 $\mathrm{mg} / \mathrm{l}+$ IBA $100 \mathrm{mg} / \mathrm{l}(16.66 \%)$. The minimum sprouting $(6.67 \%)$ was observed in the control. Among the genotypes, the per cent sprouting was significantly more in $C$ haematocephala $(47.33 \%)$, followed by $P$ venusta $(8.66 \%), C$ splendens $(7.33 \%)$, and $C$ biflora $(7.33 \%)$, whereas, the interaction was non significant in all the genotypes. Likewise, hardwood cutting treated with different growth regulator concentration and planted after callusing had significant effect on per cent sprouting even 60 days after planting in all the genotypes (Table 3 ). The mean per cent sprouting was significantly higher in T6: IBA $500 \mathrm{mg} / 1$ (28.33\%) than all the other treatments, however, the differences were non significant among T5: IBA $300 \mathrm{mg} / \mathrm{l}$ (21.67\%), T9: NAA $100 \mathrm{mg} / \mathrm{l}+$ IBA $100 \mathrm{mg} / \mathrm{l}$ (21.67\%), and T3: NAA $500 \mathrm{mg} / \mathrm{l}(18.33 \%)$. The minimum sprouting $(3.33 \%)$ was observed in the control. Among the genotypes, the per cent sprouting was significantly more in $C$ haematocephala $(48.67 \%)$ followed by $P$ venusta (6.67\%), C splendens (2.67\%), whereas, Cassia biflora failed to exhibit sprouting. In $C$ haematocephala, the per cent sprouting (93.33\%) was significantly more in T6: IBA $500 \mathrm{mg} / \mathrm{l}$ than all the other treatments and minimum $(13.33 \%)$ in the control.

The present findings regarding successful sprouting after long duration treatment of cuttings with growth regulators were in confirmation with the earlier findings in Hamelia patens with IBA (500 ppm) treatment of Alshammary and Shahba (2013). Nautiyal et al. (1991) also observed that Tectona grandis produced the best rooting when treated with IBA 100 ppm for 24 $\mathrm{h}$ and planted in soil: sand mixture $(2: 1)$ in the pots. In Hamelia patens, hardwood cutting treated with IBA $500 \mathrm{ppm}$ resulted in significantly more sprouting (77.5\%), irrespective of duration of treatment $(12,24$ h) and method of planting (Singh, 2000). The enhancing effect with growth regulators might be due to enhanced hydrolysis of carbohydrates accumulation of metabolites at the site of application of auxins, synthesis of new proteins, cell enlargement and cell division induced by auxins (Strydem and Hartman, 1960). The hardwood cuttings of Flordaguard peach (Prunus persica L. Batch) treated with 3000 ppm IBA exhibit best vegetative growth and rooting percentage (Kaur, 2017). The shoot cuttings of Couroupita guianensis (Nagalingam) resulted in maximum $(79 \%)$ of stem cuttings response to pre treatment with $300 \mathrm{mg} \mathrm{L}^{-1}$ indole-3-butyric acid (Shekhawat et al., 2016).

\section{Conclusion}


In all the four genotypes $C$ haematocephala, $C$ biflora, $P$ venusta, and $C$ splendens, treatment of cuttings with T6: IBA $500 \mathrm{mg} / \mathrm{l}$ planted directly resulted in the maximum $(33.33 \%)$ mean per cent sprouting 60 days after planting. Likewise, the cuttings treated with T6: IBA $(500 \mathrm{mg} / \mathrm{l})$ and planted in sand bed for callusing resulted in the maximum $(28.33 \%)$ mean per cent sprouting, 60 days after planting. The treatment of cutting with IBA $500 \mathrm{mg} / \mathrm{l}$ and planting directly in soil help in better sprouting of cutting which otherwise difficult to propagate through hardwood cutting.

\section{REFERENCES}

Akhtar, G., Akram, A., Sajjad, Y., Balal, R.M., Shahid, M.A., Sardar, H., Naseem, K. and Shahm S.M. (2015). Potential of plant growth regulators on modulating rooting of Rosa centifolia. Am. J. Plant Sci., 6: 659-65.

Alshammary, S. F. and Shahba, M. A. (2013). Rooting of firebush shrub hardwood cuttings using growth regulator long duration application. J. Food Agric. Environ., 11:2283-88.

Arora, J. S., (2013) Introductory Ornamental Horticulture. Kalyani Publishers, New Delhi, India.

Bhatt, B. P. and Badoni, A. K. (1993). Studies on vegetative propagation in Ficus glomerata L. Moraceae stem cutting. Indian forester, 119(3):247-251.

Bhatt, B. P. and Todaria, N. P. (1990). Seasonal rooting behaviour of stem cuttings of some agroforestry tree species of Garhwal Himalaya. Ind. J. For.,13(4):362-364.

Chauhan, D. S., Bhatt, B. P. and Todaria, N. P. (1996). Seasonal rooting and nodulation response in Desmodium elegans as influenced by exogenous application. $J$. Trop. For. Sci.,9:67-74.

Cong, X. (1991). Studies on reproduction with green cutting of Prunus triloba var. plena. Acta Hort.Sinica.,18:27880.

Fisher, R. A. (1950). Statistical method for research works. Oiver and Boyd Edinburg. p-248-98.

Hartmann, T. H., Kester. D. E., Davies, F. T. and Geneve, R. L. (2009).Technique of propagation by cuttings. Plant propagation principal and practices. PHI Learning Private Limited, New Delhi.

Ingole, M. V., Gajbhiye, R. P., Ghormade, G. N., and Bhande, M. H. (2016). Effect of IBA and types of cuttings on rooting in Ficus benjamina (L.). Journal of Soils and Crops, 26(2): 302-05.
Jamal, A., Ayub, G., Rahman, A., Rashid, A., Ali, J., and Shahab, M. (2016). Effect of IBA (Indole Butyric Acid) levels on the growth and rooting of different cutting types of Clerodendrum splendens. Pure Appl. Biol., 5(1): 64-71.

Joshi, N. K., Sharma, S., Shamet, G. S. and Dhiman, R. C. (1992). Studies on effect of auxin and season on rooting stem cutting of some important shrubs in nursery beds. Indian Forester, 118: 893-900.

Karami, A.and Salehi, H. (2010). Adventitious root formation in Rohida (Tecomella undulata(Sm.) seem) cutting. Propagation of Ornamental Plants 10:163-65.

Kaur. S., (2017). Evaluation of different doses of indole-3butyric acid (IBA) on the rooting, survival and vegetative growth performance of hardwood cuttings of Flordaguard peach (Prunus persica L. Batch). Journal of Applied and Natural Science, 9 (1): $173-180$.

Masoodi, N. A, Srivastva, L. J. and Mir, N. A. (1994). Studies on the effect of growth regulators on initiation of rooting in cuttings of Glycyrrhiza blabra Linn. Indian J. Physiol., 37:28-29.

Nautiyal, S., Uma, S., Gwiumuriti and Singh, U. (1991). Rooting response of branch cutting of teak (Tectonagrandis) as influenced by season and growth hormones. Indian Forester, 117: 249-55.

Ratnamala, M., Kumar, B.P., Swami, D.V. and Suneetha, D.R.S. (2014). Effect of auxins and type of cutting on propagation of phalsa (Grewia subinaequalis DC.) under shade net condition. Green Farming, 5 (3): 419-423.

Ribeiro, M. M., Collado, L. M. and Antunes, M. A. (2010). The influence of indole-3-butyric-acid in Prunus Laurocerasus vegetative propagation. Acta Hort, 885.

Shekhawat, M. S. and Manokari, M. (2016). Impact of Auxins on Vegetative Propagation through Stem Cuttings of Couroupita guianensis Aubl.: A Conservation Approach. Scientific, p-1-7.

Singh, S. (2000).Effect of growth regulator treatment on rooting and propagation of ornamental shrubs. M.Sc. thesis, Punjab Agricultural University, Ludhiana, India.

Sofi, P. A., Bhat, S. A., Masoodi, T. H., Islam, M. A., Bhat, G. M. and Malik, A. R. (2016). Propagation of Himalayan maple (Acer caesium Wall.) through seed and softwood cuttings. Journal of Applied and Natural Science, 8 (3): 1235-40.

Strydem, D.K. and Hartman, H.T. (1960). Effect of indole butyric acid and respiration and nitrogen metabolism in Marianna 2624 plum softwood stem cuttings. Proc. Amer. Soc. Hort., 45(1-2): 81-82. 